\title{
MICROSTRUCTURE AND PROPERTY EVOLUTION OF THE 1538MV NON-QUENCHED AND TEMPERED STEEL FOR A CRANKSHAFT DURING THE FORGING PROCESS
}

\section{RAZVOJ MIKROSTRUKTURE IN LASTNOSTI ROČIČNE GREDI IZ NEKALJENEGA IN POBOLJŠANEGA JEKLA 1538MV MED KOVANJEM}

\author{
Yang Yong ${ }^{1,2}$, Le-yu Zhou' ${ }^{2}$, Dian-yu Fu² ${ }^{2}$, Peng Jiang ${ }^{2}$, Xue-ping Ren ${ }^{1}$ \\ ${ }^{1}$ University of Science \& Technology Beijing, School of Materials Science and Technology, no. 30 Xue Yuan Road, \\ Hai Dian District, Beijing, 100083, China \\ ${ }^{2}$ Beijing Research Institute of Mechanical \& Electrical Technology Limited Company, Forging Technology Center, no. 18 Xue Qing Road, Hai \\ Dian District, Beijing, 100083, China \\ yy19821110@163.com
}

Prejem rokopisa - received: 2018-01-19; sprejem za objavo - accepted for publication: 2018-03-08

\author{
doi:10.17222/mit.2018.011
}

\begin{abstract}
The microstructure, properties and precipitation of rolled bars and a crankshaft were studied with experiments and numerica simulations. Compared with the rolled bars, the microstructure of the crankshaft was coarsened, and the volume fraction of ferrite decreased because of the uneven strain, the metal flow and the fast cooling rate during the forging process. The main precipitation in ferrite involved $\mathrm{V}(\mathrm{C}, \mathrm{N})$ particles, which became more dispersed after the forging. As a result, the strength of the crankshaft was higher than that of the rolled bars, while the plasticity was lower. The results provided some additional information about the quality improvement of rolled bars and the basis for optimizing the crankshaft-forging process.

Keywords: non-quenched and tempered steel, precipitation, crankshafts, microstructure, numerical simulations
\end{abstract}

Avtorji prispevka so eksperimentalno in s pomočjo numeričnih simulacij preučevali mikrostrukturo, lastnosti in izločevalno utrjevanje valjanih palic in ročične gredi. V primerjavi z valjanimi palicami je bila mikrostruktura ročičnih gredi grobozrnata in volumski delež ferita se je zmanjšal zaradi neenakomernih deformacij, plastičnega toka kovine in hitrega ohlajanja med kovanjem. Glavni proces precipitacije iz ferita je potekal v obliki izločanja V (C, N) delcev, ki so bili po kovanju bolj enakomerno porazdeljeni po kovinski osnovi. Posledično so imele ročične gredi večjo trdnost, a manjšo plastičnost (duktilnost in žilavost) kot valjane palice. Rezultati študije so avtorjem omogočili pridobiti nekaj dodatnih informacij o izboljšanju valjanih palic in bili osnova za optimiranje procesa kovanja ročičnih gredi.

Ključne besede: nekaljeno in poboljšano jeklo, izločanje, ročične gredi, mikrostruktura, numerične simulacije

\section{INTRODUCTION}

Non-quenched and tempered (NQ\&T) steel is based on medium- and high-carbon steel made by adding a certain amount of micro-alloy elements, which can exhibit the mechanical properties of the quenched and tempered steels without quenching or tempering after the deformation. Comparing it with quenched and tempered steel, NQ\&T steel has many advantages such as energy saving, emission reduction, simple processing, short production, low costs, etc. ${ }^{1-5}$

The crankshaft is an important part of the automobile engine. ${ }^{6-8}$ The final microstructure is very important as it directly affects the service life of the crankshaft. The pressure to save energy and reduce emissions is increasing with the rapid increase in the car production and ownership. As a result, the usage of NQ\&T steel for automotive parts is attracting more and more attention. There are more and more researches on the forging and structural properties of NQ\&T steel crankshafts. ${ }^{9-12}$

The microstructure and mechanical properties of 38MnNS5 NQ\&T steel crankshafts at different forging temperatures and different cooling processes after the forging were analyzed..$^{13}$ In order to control the magnetic mark defect, the effects of the cumulative reduction, pass reduction and deformation temperature on the evolution of the quantity, size and morphology of $\mathrm{MnS}$ inclusions during the rolling of the NQ\&T crankshaft steel C38N2 were studied. ${ }^{14}$ The microstructure-refinement effect of alloying elements $\mathrm{Nb}, \mathrm{Ti}$ and $\mathrm{S}$ was investigated by analyzing the austenite grain growth behavior and hot-rolled microstructure of a non-quenched steel for crankshafts. ${ }^{15}$ The effects of the heating temperature and cooling speed on the number of ferrite grains, the average diameter of ferrite grains and the volume percentage of ferrite were analyzed. ${ }^{16}$ During the research of the die-forging technology for crankshafts made of non-quenched steel, Deform-3D software was used to simulate the forming of a crankshaft. ${ }^{17}$

Many processes are needed to forge a crankshaft because of its complex shape. In such a complex forming process, the metal flow is severe, and the strain is nonuniform. These factors have large influences on the mic- 
Y. YONG et al.: MICROSTRUCTURE AND PROPERTY EVOLUTION OF THE 1538MV ...

Table 1: Chemical composition

\begin{tabular}{|c|c|c|c|c|c|c|c|c|c|}
\hline \multirow{2}{*}{ Alloy } & \multicolumn{9}{c|}{ Elements $(w / \%)$} \\
\cline { 2 - 11 } & & $\mathrm{C}$ & $\mathrm{Si}$ & $\mathrm{Mn}$ & $\mathrm{P}$ & $\mathrm{S}$ & $\mathrm{Cr}$ & $\mathrm{V}$ & $\mathrm{N}$ \\
\hline \multirow{2}{*}{$1538 \mathrm{MV}$} & Composition range & $0.36-0.41$ & $0.5-0.65$ & $1.3-1.45$ & $\max .0 .015$ & $0.05-0.065$ & $0.1-0.2$ & $0.06-0.09$ & - \\
\cline { 2 - 11 } & Measured value & 0.38 & 0.56 & 1.39 & $\max .0 .015$ & 0.61 & 0.16 & 0.08 & 0.011 \\
\hline
\end{tabular}

rostructure of NQ\&T crankshafts after the forging. ${ }^{18-22}$ The microstructure optimization of crankshafts is very important as it directly affects their mechanical properties and service life.

$1538 \mathrm{MV}$ is a kind of pearlite + ferrite NQ\&T steel and its application for crankshafts has not been studied sufficiently. In this study, based on a numerical-simulation analysis, the microstructures and mechanical properties of rolled bars and crankshafts were compared and analyzed. The microstructure evolution of the 1538MV material during the forging process was determined, providing some supplementary information about improving the quality of $1538 \mathrm{MV}$ NQ\&T steel crankshafts.

\section{EXPERIMENTAL PART}

\subsection{Materials}

Rolled bars and crankshaft forgings were obtained from a forging workshop, and the material was $1538 \mathrm{MV}$. The crankshaft forgings were produced on a 4000-ton hot-die forging press. The initial forging temperature was $1180{ }^{\circ} \mathrm{C}$, and the forgings were air cooled directly after the forging. Their chemical composition is shown in Table 1. The forging of a crankshaft is shown in Figure 1: the diameter of the rolled bar is $85 \mathrm{~mm}$; the diameters of the main journal and connecting-rod journal were $54 \mathrm{~mm}$ and $39 \mathrm{~mm}$, respectively. The mechanical properties of the rolled bar and crankshaft were obtained with tensile tests.

Samples were cut from the rolled bar, main journal and connecting-rod journal. Sampling positions included the surface, radius midpoint and core, in which the main journal and connecting-rod journal were sampled along the flash side. The grain size and structure content were measured using the Image Tool analysis software. The microstructure was observed using optical microscopy and transmission electron microscopy:

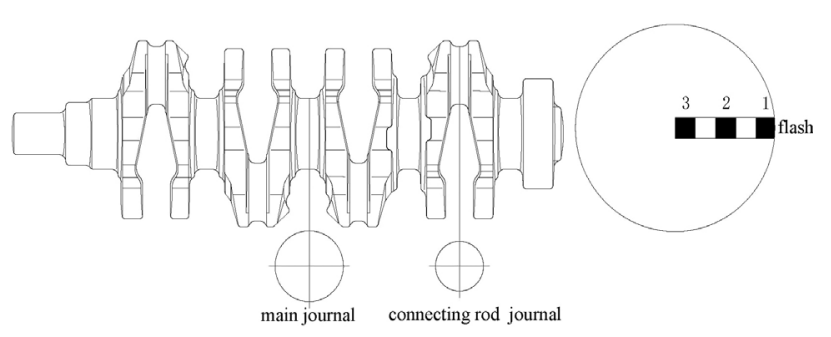

Figure 1: Sampling sections of the crankshaft: 1) edge, 2) radius midpoint, 3) core
1) The samples were polished and etched with 4-\% nital, then observed with a ZEISS AxioScope A1 optical microscope.

2) The TEM samples were prepared with mechanical and chemical thinning methods and observed with a EM-2100 (HR) transmission electron microscope.

The amounts of the elements from different positions of the rolled bars were measured with a direct-reading spectrometer, as shown in Table 2. It can be seen that the amounts of $\mathrm{C}, \mathrm{Mn}, \mathrm{S}$ and $\mathrm{Cr}$ in the core and radius midpoint were higher than those in the surface, especially in the core area. The element-segregation zone was near the radius-midpoint area.

Table 2: Chemical composition in different positions of rolled material

\begin{tabular}{|c|c|c|c|c|c|c|c|}
\hline \multirow{2}{*}{ position } & \multicolumn{7}{|c|}{ Elements $(w / \%)$} \\
\cline { 2 - 8 } & $\mathrm{C}$ & $\mathrm{Si}$ & $\mathrm{Mn}$ & $\mathrm{P}$ & $\mathrm{S}$ & $\mathrm{Cr}$ & $\mathrm{V}$ \\
\hline core & 0.406 & 0.587 & 1.44 & 0.012 & 0.094 & 0.182 & 0.087 \\
\hline $\begin{array}{c}\text { radius } \\
\text { midpoint }\end{array}$ & 0.383 & 0.576 & 1.40 & 0.010 & 0.065 & 0.178 & 0.080 \\
\hline surface & 0.376 & 0.573 & 1.37 & 0.010 & 0.062 & 0.175 & 0.079 \\
\hline
\end{tabular}

\subsection{Numerical simulation}

To analyze the strain distribution and metal flow, the forging process of a crankshaft was simulated with the Deform-3D software. The relevant data obtained through thermal simulation experiments were imported into the Deform material library and the mold was set as a rigid body. Simulated parameters and boundary conditions were chosen according to the forging parameters. The initial temperature of the die was $200{ }^{\circ} \mathrm{C}$, the initial temperature of the blank was $1180{ }^{\circ} \mathrm{C}$ and the environment temperature was $20^{\circ} \mathrm{C}$. The forging speed of the die was $240 \mathrm{~mm} / \mathrm{s}$. The friction coefficient between the blank and the die was 0.3 . The heat-transfer coefficient between the blank and die was $11 \mathrm{~N} /\left(\mathrm{s} \mathrm{mm}^{\circ} \mathrm{C}\right)$, and the-heat transfer coefficient between the blank and air was $0.02 \mathrm{~N} /\left(\mathrm{s} \mathrm{mm}^{\circ} \mathrm{C}\right)$.

\section{RESULTS AND DISCUSSION}

\subsection{Numerical simulation results}

As shown in Figure 2, the cross-section of a round bar was marked in the circumferential direction and the metal flow of the crankshaft's main journal and connecting-rod journal was simulated. The metal-flow trajectory was a space curve and the cross-sectional view was taken along the center of the vertical main journal. The results showed the following: the crankshaft's 


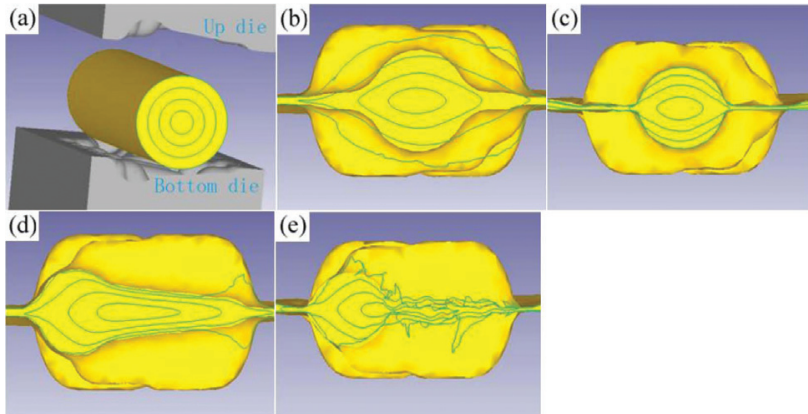

Figure 2: Metal flow during the forging process: a) rolled material, b) main journal after pre-forging, c) main journal after final forging, d) connecting-rod journal after pre-forging, e) connecting-rod journal after final forging
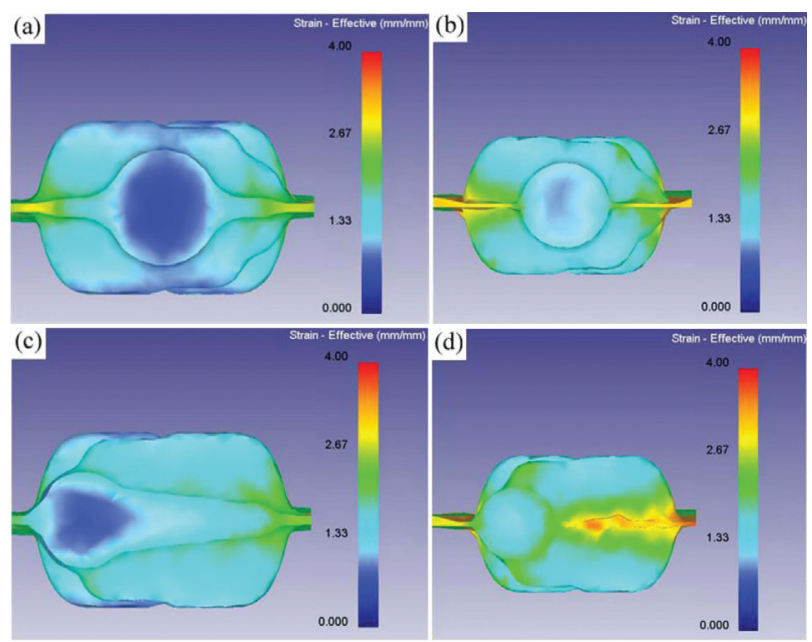

Figure 3: Strain distribution after forging: a) main journal after pre-forging, b) main journal after finial forging, c) connecting-rod journal after pre-forging, d) connecting-rod journal after finial forging forging deformation was uneven, the metal at the center of the raw material flowed to the center of the main journal and the inner side of the parting surface of the connecting-rod journal, the metal at the radius midpoint flowed to the parting-surface edge of the main journal and the center of the connecting-rod journal, and the metal at edge flowed to the flash of the main journal and the parting-surface outer edge of the connecting-rod journal.

The strain distribution on the main journal and connecting-rod journal after the forging is shown in Figure 3. It could be seen that the strain at the surface of the main journal and connecting-rod journal was higher than the strain in their centers because of a severe deformation of the metal at the flash. In addition, the strain of the connecting-rod journal was higher than that of the main journal because the connecting-rod journal's section was smaller and the deformation was larger.

\subsection{Microstructural analysis}

The surface microstructures of the rolled bar, crankshaft's main journal and connecting-rod journal are shown in Figure 4. The radius-midpoint microstructures of the rolled bar, crankshaft's main journal and connecting-rod journal are shown in Figure 5. The core microstructures of the rolled bar, crankshaft's main journal and connecting-rod journal are shown in Figure 6.

The quantitative analysis of the surface microstructures of the rolled bar, main journal and connecting-rod journal showed that the volume fraction of ferrite was about $(26.5,14.8$ and 16$) \%$, and the average grain size of the original austenite was $(61,78$ and 97) $\mu \mathrm{m}$. The rolled-bar surface microstructure had a higher ferrite
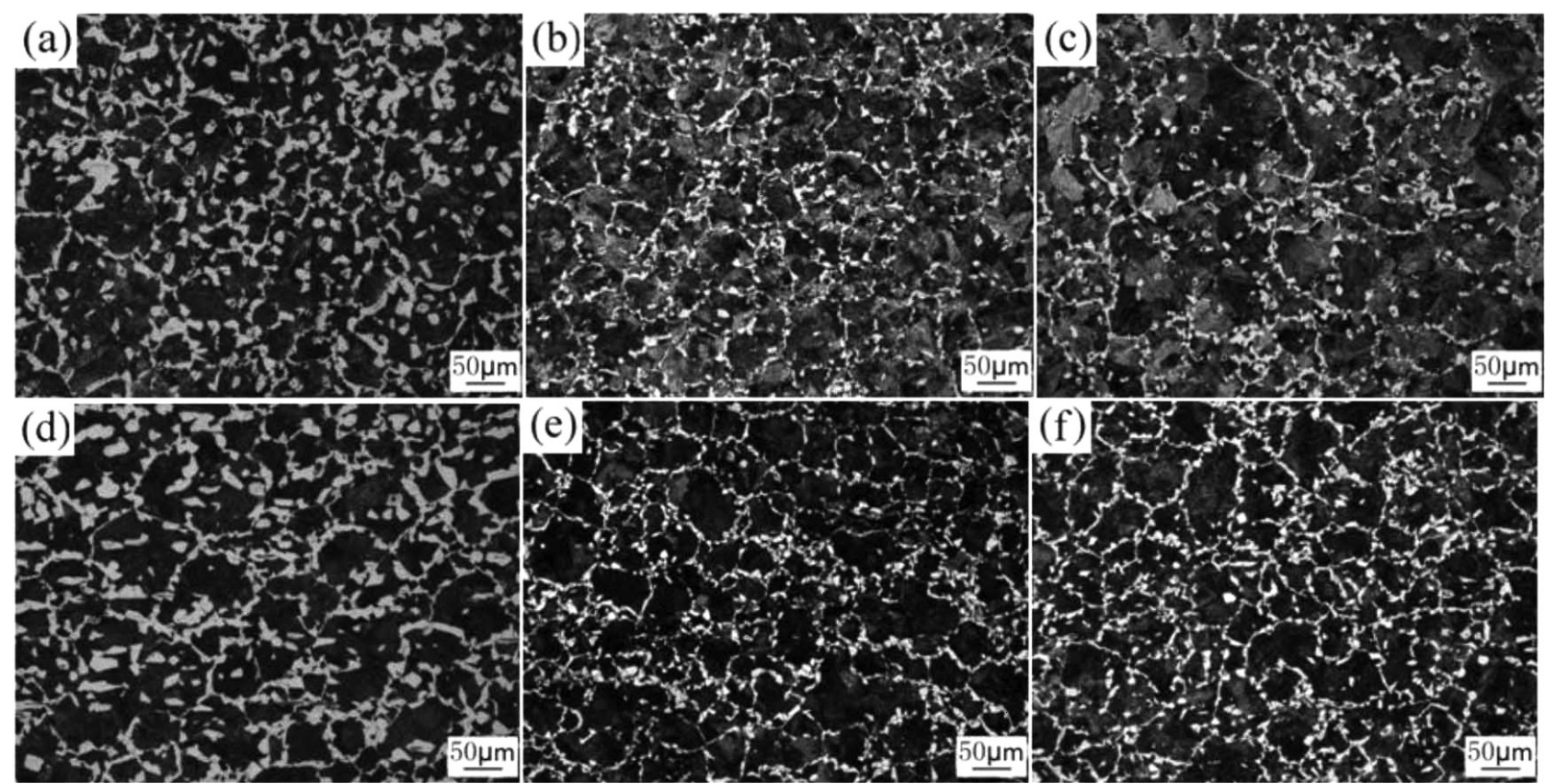

Figure 4: Microstructure of the surface: a) rolled bar - longitudinal section (26.5\% ferrite), b) main journal - longitudinal section (14.8 \% ferrite), c) connecting-rod journal - longitudinal section (16\% ferrite), d) rolled bar - cross-section (26.5\% ferrite), e) main journal - cross-section (14.8\% ferrite), f) connecting-rod journal - cross-section (16\% ferrite) 

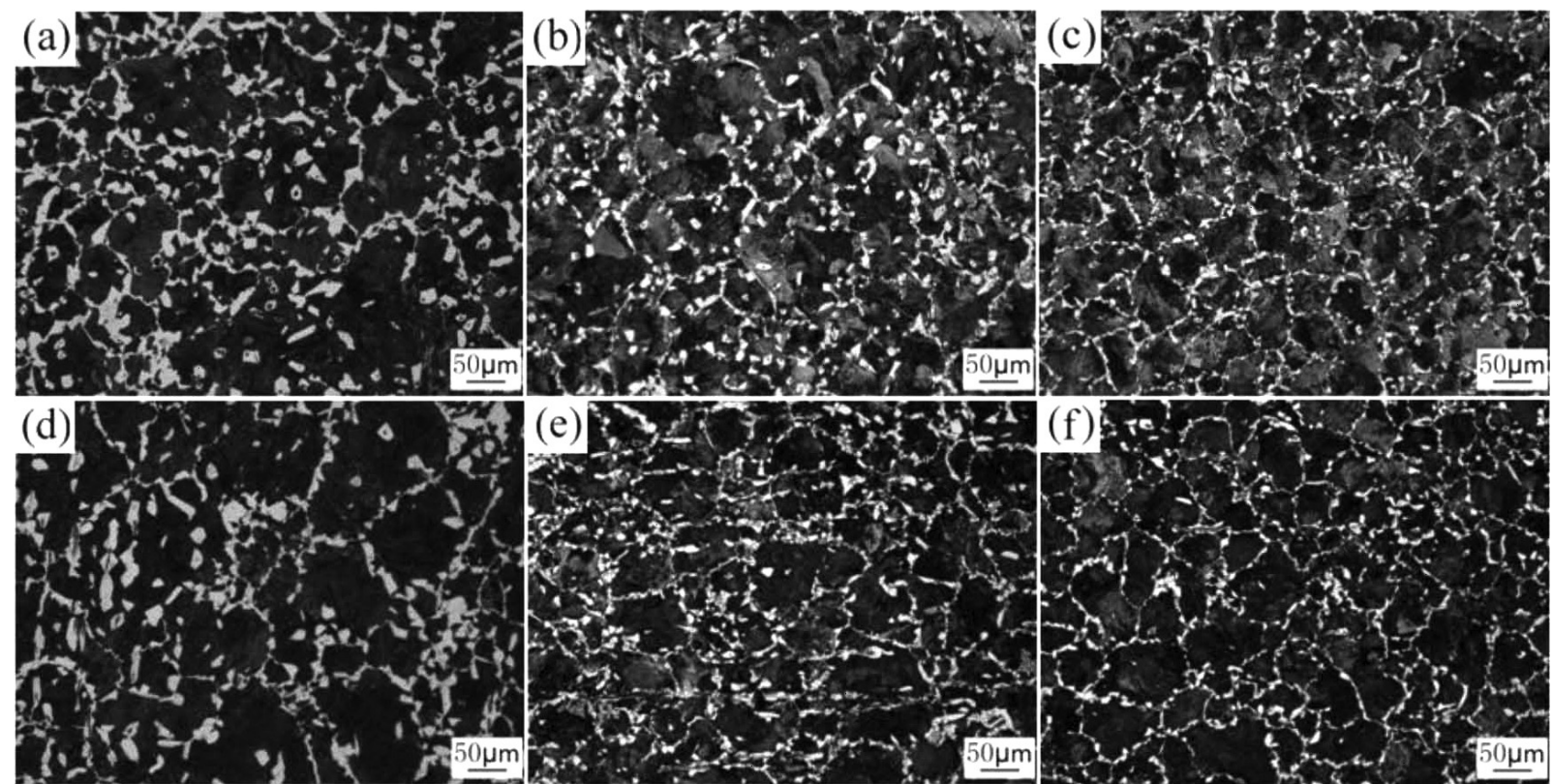

Figure 5: Microstructure of the radius midpoint: a) rolled bar - longitudinal section (18.6\% ferrite), b) main journal - longitudinal section $(15.6 \%$ ferrite), c) connecting-rod journal - longitudinal section (11.6\% ferrite), d) rolled bar - cross-section (18.6\% ferrite), e) main journal cross-section ( $15.6 \%$ ferrite), f) connecting-rod journal - cross-section (11.6\% ferrite)
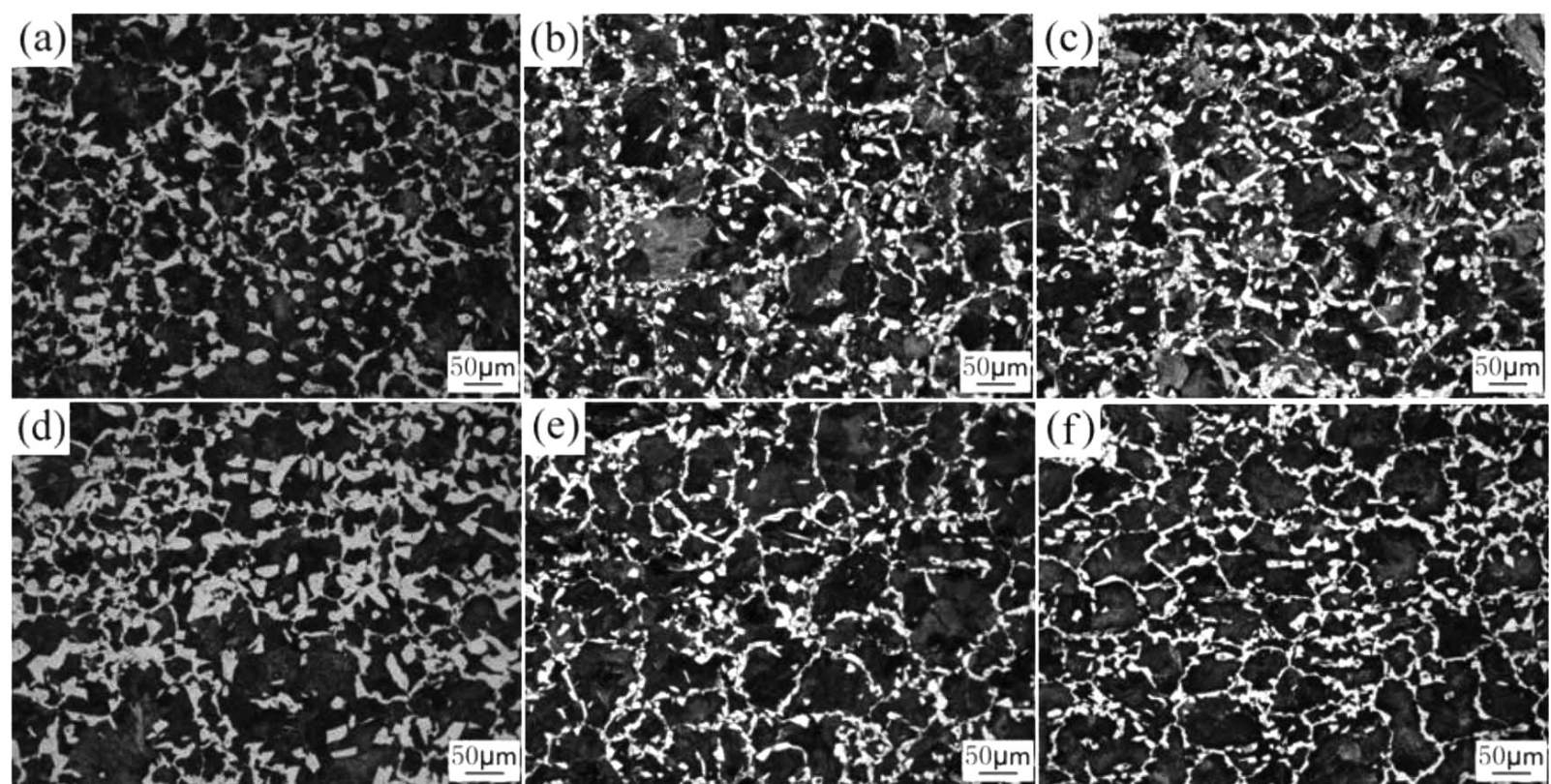

Figure 6: Microstructures of the core: a) rolled bar - longitudinal section (23.8 \% ferrite), b) main journal - longitudinal section (19.2 \% ferrite), c) connecting-rod journal - longitudinal section (20.8\% ferrite), d) rolled bar - cross-section (23.8 \% ferrite), e) main journal - cross-section (19.2\% ferrite), f) connecting-rod journal - cross-section (20.8\% ferrite)

content and finer austenite grains. The structure was coarsened after the forging, especially in the surface of the connecting-rod journal. The crankshaft forging requires a high forging temperature, which promoted the growth of the austenite grains. This could be seen from the metal flow during the simulation process. The rolled-bar radius-midpoint metal flowed to the mainjournal surface, and the core metal flowed to the con- necting-rod-journal surface. Continuous-casting material exhibits a positive segregation of the alloying elements at the radius-midpoint location, so the amounts of ferrite in the main-journal surface and connecting-rod-journal surface were lower.

The quantitative analysis of the radius-midpoint microstructures of the rolled bar, main journal and connecting-rod journal showed that the volume fraction 
of ferrite was about $(18.6,15.6$ and 11.6$) \%$, and the average grain size of the original austenite was $(83,99$ and 85$) \mu \mathrm{m}$. It could be seen that the radius midpoint of the rolled bar had a higher ferrite content and the structure was coarsened after the forging. Rolled-bar heating also promoted the austenite grain growth. Due to the larger cross-section of the main journal and smaller deformation, the austenite grain size at the radius midpoint of the main journal was the largest. The main-journal grain size was the largest, so the ferrite amount should have been reduced. However, the cooling speed of the connecting-rod journal was faster than that of the main journal, which made its ferrite amount lower than that of the main journal.

The quantitative analysis of the core microstructures of the rolled material, main journal and connecting-rod journal showed that the volume fraction of ferrite was about $(23.8,19.2$ and 20.8) \%, and the average grain size of the original austenite was $(90,109$ and 107) $\mu \mathrm{m}$. After the forging, the ferrite amount at the core of the main journal and connecting-rod journal was reduced a little, and the austenite grain was coarsened because of the heating of the rolled bar. The main journal had a small deformation and the average grain size of austenite was slightly larger but less obvious than that of the connecting-rod journal. Because the core of the main journal adopted the rolled-material segregation zone, the ferrite amount was low. The core of the connecting-rod journal also adopted the segregation zone, but due to a large deformation and deformation-induced ferrite transformation, the ferrite amount was slightly higher than that of the main journal.

After the forging, the ferrite amount of the crankshaft was decreased and the austenite grains were coarsened. To improve the metal fluidity and ensure good cavity filling, the forging temperature of the crankshaft was

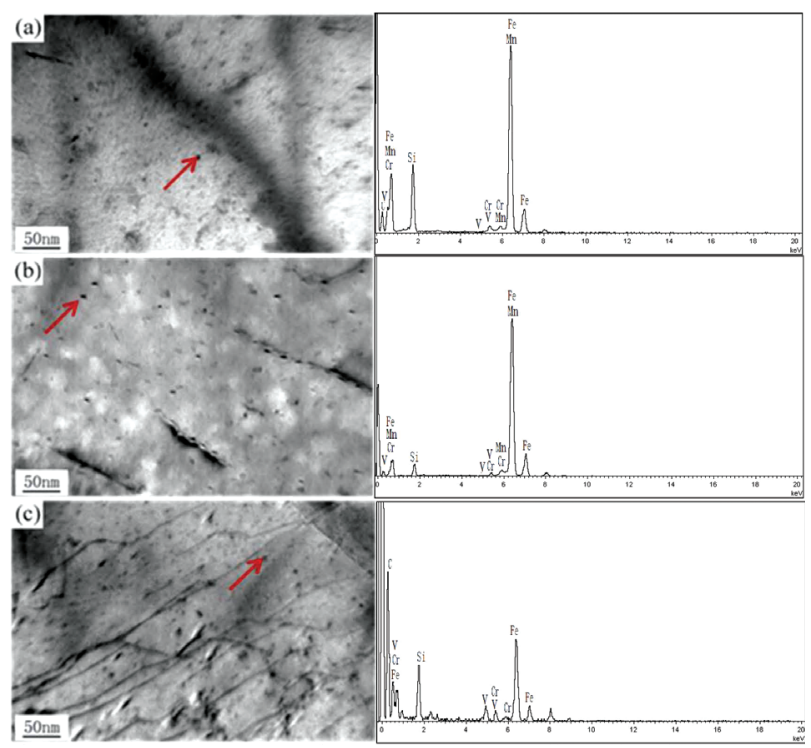

Figure 7: TEM morphology of precipitates and EDS results: a) rolled bar, b) main journal, c) connecting-rod journal often high. Moreover, the forging deformation of the crankshaft was smaller than that of the rolled bar, which made the microstructure of the crankshaft coarser than that of the rolled bar. In addition, the deformation of the crankshaft was very uneven, the microstructure at the position of the larger deformation was finer than that at the position of the smaller deformation. It should be noted that the rapid cooling rate in the phase transition zone and the flow of the segregation zone had significant influences on the microstructure of the crankshaft, resulting in a decrease of the ferrite amount after the forging. Moreover, the flow of the segregation zone to the surface of the crankshaft could also easily cause a magnetic flaw. To refine the forging microstructure, improve the strength and toughness of the crankshaft, the quality of the rolled bar should be strictly controlled and the forging of the crankshaft should be optimized.

\subsection{Precipitate composition and morphology}

The precipitates in the ferrite of the rolled bar, crankshaft's main journal and connecting-rod journal were observed and analyzed with a transmission electron microscope. TEM morphology and EDS results for the precipitates are shown in Figure 7.

The precipitates were mostly round, some were strip shaped. The size of the precipitates in the ferrite was about 8.5-11 nm, and the energy-spectrum analysis showed that the precipitates were $\mathrm{V}(\mathrm{C}, \mathrm{N})$ particles. The precipitates in the ferrite of the main journal were distributed uniformly, and their quantity was higher than in the rolled bar, which tended to be dispersed, having some parallel precipitates between the phases. Here, the size of the precipitates was about $4.5-8 \mathrm{~nm}$, and the energy-spectrum analysis showed that the precipitates were $\mathrm{V}(\mathrm{C}, \mathrm{N})$ particles. There were many single precipitates distributed evenly in the ferrite of the connectingrod journal. The precipitates were $\mathrm{V}(\mathrm{C}, \mathrm{N})$ particles; the size was about 5-9 nm, and there was a large number of nano-vanadium precipitates agglomerated together.

$\mathrm{V}$ is one of the strengthening ferrite elements. It has extremely strong affinity with $\mathrm{C}$ and $\mathrm{N}$ to form a stable compound. The 1538MV NQ\&T steel contains a few V elements which can precipitate vanadium carbonitride. Compared with the rolled bar, the size of the precipitates had a refining trend; the quantity was increased and the distribution was dispersed. The size, quantity and distribution of the precipitates were affected by the forging temperature and cooling rate after the forging. Therefore, in addition to controlling the reasonable forging temperature, the cooling process should be further optimized to ensure a reasonable ferrite shape, size and volume fraction.

\subsection{Mechanical-property analysis}

Five rolled bars and their corresponding forgings were selected for tracking experiments. The mechanical 
properties of the rolled bars and crankshafts are shown in Tables 3 and 4. For the crankshaft, compared with the rolled bar, the tensile strength increased by 20-40 MPa, the yield strength increased by 30-70 MPa, the Brinell hardness increased 2-15 HB, the elongation decreased by $6.8-8.6 \%$, and the shrinkage ratio decreased by $3-11 \%$

Table 3: Mechanical properties of the rolled material

\begin{tabular}{|c|c|c|c|c|c|}
\hline No. & $\begin{array}{c}\text { Tensile } \\
\text { strength } \\
(\mathrm{MPa})\end{array}$ & $\begin{array}{c}\text { Yield } \\
\text { strength } \\
(\mathrm{MPa})\end{array}$ & $\begin{array}{c}\text { Elon- } \\
\text { gation } \\
(\%)\end{array}$ & $\begin{array}{c}\text { Shrinkage } \\
\text { ratio } \\
(\%)\end{array}$ & $\begin{array}{c}\text { Hardness } \\
(\mathrm{HB})\end{array}$ \\
\hline 1 & 858 & 585 & 22 & 48 & 250 \\
\hline 2 & 850 & 585 & 20.5 & 48 & 249 \\
\hline 3 & 905 & 640 & 20 & 43 & 248 \\
\hline 4 & 903 & 619 & 19.5 & 45 & 264 \\
\hline 5 & 882 & 585 & 20.5 & 45 & 256 \\
\hline
\end{tabular}

Table 4: Mechanical properties of the crankshaft

\begin{tabular}{|c|c|c|c|c|c|}
\hline No. & $\begin{array}{c}\text { Tensile } \\
\text { strength } \\
(\mathrm{MPa})\end{array}$ & $\begin{array}{c}\text { Yield } \\
\text { strength } \\
(\mathrm{MPa})\end{array}$ & $\begin{array}{c}\text { Elon- } \\
\text { gation } \\
(\%)\end{array}$ & $\begin{array}{c}\text { Shrinkage } \\
\text { ratio } \\
(\%)\end{array}$ & $\begin{array}{c}\text { Hardness } \\
(\mathrm{HB})\end{array}$ \\
\hline 1 & 900 & 654 & 14.1 & 38.9 & 259 \\
\hline 2 & 894 & 616 & 12.0 & 36.6 & 255 \\
\hline 3 & 930 & 668 & 11.5 & 39.8 & 263 \\
\hline 4 & 921 & 694 & 12.7 & 37.0 & 266 \\
\hline 5 & 903 & 633 & 13.3 & 39.5 & 267 \\
\hline
\end{tabular}

The changes in the mechanical properties of the crankshafts after the forging were caused by the following changes in the microstructural characteristics: the austenite grains were coarsened, the ferrite amount was reduced, the quantity of the nano-vanadium precipitates was increased, the size tended to be fine and the distribution was dispersed. These microstructural characteristics led to the fine-grain strengthening and precipitation strengthening; furthermore, they resulted in increased strength and hardness, and reduced plasticity.

\section{CONCLUSIONS}

1) After the forging, the ferrite amount of the crankshaft decreased and the austenite grains coarsened. A higher forging temperature and smaller deformation made the microstructure of the crankshaft coarse. The rapid cooling rate in the phase-transition zone and the flow of the segregation zone had significant influences on the microstructure of the crankshaft, resulting in a decrease in the ferrite amount after the forging.

2) The size of the precipitates had a refining trend, the quantity increased and the distribution was dispersed after the forging. The size, quantity and distribution of the precipitates were affected by the forging temperature and cooling rate after the forging. Therefore, in addition to controlling the reasonable forging temperature, the cooling process should be further optimized.
3) The crankshaft's strength and hardness increased, while the plasticity was reduced. The changes in the mechanical properties were caused by the changes in the microstructural characteristics. Therefore, the microstructure of a crankshaft should be strictly controlled to ensure its overall mechanical properties.

\section{REFERENCES}

${ }^{1}$ L. Y. Zhou, B. Jiang, M. Y. Li, Microstructure control of nonquenched and tempered CT80 grade coiled tubing steel, Acta Metallurgica Sinica (English Letters), 27 (2014) 3, 464-468, doi:10.1007/s40195-014-0063-1

${ }^{2}$ P. Hyounsoo, S. K. Yong, C. J. Seung, Development of fracture split steel connecting rods, Innovations in Steel Sheet and Bar Products, (2003), 91-95, doi:10.4271/2003-01-1309

${ }^{3}$ Y. Luo, J. M. Peng, H. B. Wang, Effect of tempering on microstructure and mechanical properties of a non-quenched bainitic steel, Materials Science and Engineering A, 527 (2010) 15, 3427-3433, doi:10.1016/j.msea.2010.02.010

${ }^{4}$ S. D. Gu, L. W. Zhang, J. H. Ruan, Constitutive modeling of dynamic recrystallization behavior and processing map of 38MnVS6 non-quenched steel, Journal of Materials Engineering and Performance, 23 (2014) 3, 1062-1068, doi:10.1007/s11665-0130808-4

${ }^{5}$ F. A. Khalid, Precipitation and compositional changes in the structural phases of microalloyed automotive steels, Materials Science and Engineering, 325 (2002) 1/2, 281-285, doi:10.1016/S09215093(01)01471-X

${ }^{6}$ J. Li, H. Y. Gao, N. Y. Shen, Accuracy control of balancing of crankshaft journals in grinding process based on cutting depth model, Journal of Mechanical Engineering, 53 (2017) 5,199-206, doi:10.3901/JME.2017.05.199

${ }^{7}$ L. H. Peng, A new discussion on manufacturing the bent axle in internal-combustion engine, Metal Forming Technology, 22 (2004) 2, 15-18, doi:10.3969/j.issn.1674-6457.2004.02.005

${ }^{8}$ L. M. Alves, P. A. F. Matrins, Flexible forming tool concept for producing crankshafts, Journal of Material Processing, 211 (2011) 3, 467-474, doi:10.1016/j.jmatprotec.2010.10.024

${ }^{9}$ B. Behrens, M. Stonis, T. Blohm, Investigation of simulation parameters for flash-reduced forging of two-cylinder crankshafts, Steel Research International, 87 (2016) 7, 824-828, doi:10.1002/ srin.201500279

${ }^{10}$ A. Milenin, T. Rec, W. Walczyk, Model of curvature of crankshaft blank during heat treatment, accounting for phase transformations, Steel Research International, 87 (2016) 4, 519-528, doi:10.1002/srin.201500124

${ }^{11}$ W. Walczyk, A. Milenin, M. Pietrzyk, Computer aided design of new forging technology for crank shafts, Steel Research International, 82 (2015) 3, 187-194, doi:10.1002/srin.201000121

${ }^{12}$ G. Castro, A. Fernández-Vicente, J. Cid, Influence of the nitriding time in the wear behaviour of an AISI H13 steel during a crankshaft forging process, Wear, 263 (2007) 7-12, 1375-1385, doi:10.1016/ j.wear.2007.02.007

${ }^{13}$ X. S. Ying, X. G. Dong, B. Zhou, Study on cooling process of $38 \mathrm{MnNS} 5$ non-quenched and tempered steel crankshaft after forging, Hot Working Technology, (2017) 4, 249-250, doi:10.14158/j.cnki. 1001-3814.2017.04.068

${ }^{14}$ Z. Q. Dong, B. Jiang, C. L. Zhang, Evolution of MnS in non-quenched and tempered crankshaft steel C38N2 during rolling, Transactions of Materials and Heat Treatment, 36 (2015) 8, 144-149, doi:10.13289/j.issn.1009-6264.2015.08.026

${ }^{15}$ C. L. Zhang, Z. Yang, J. H. Sun, Effect of alloying elements on austenite grain growth and microstructure refinement in a nonquenched steel for crankshafts, Chinese Journal of Engineering, 37 (2015) 2, 175-179, doi:10.13374/j.issn2095-389.2015.02.006 
${ }^{16}$ F. Yan, W. N. Yang, P. Jiang, Thermal simulation test analysis of non-quenched and tempered steel crankshaft forging, Forging and Stamping Technology, 35 (2010) 4, 16-20, doi:10.3969/jissn10003940.2010.04.005

${ }^{17} \mathrm{Y}$. Ye, Study on die forging process of quenched and tempered steel crankshaft, Chongqing University of Technology, Chongqing 2012

${ }^{18}$ H. M. Ting, G. Peng, G. H. Yi, Effect of forging process on V-Nb-Ti microalloyed non-quenched and tempered steels, Advanced Materials Research, 936 (2014), 1179-1183, doi:10.4028/ www.scientific.net/AMR.936.1179

${ }^{19}$ J. H. Wei, J. Z. Yong, W. S. Cheng, Microstructural effects on high-cycle fatigue properties of microalloyed medium carbon steel 38MnVS, Materials Science and Engineering A, 640 (2015), 147-153, doi:10.1016/j.msea.2015.05.054
${ }^{20}$ Y. H. Huang, Y. Zhang, H. Zhai, Strengthening and toughening mechanisms of the microalloying non-quenching and tempering steel, Materials for Mechanical Engineering, (2005) 475-479, 97-100, doi:10.4028/www.scientific.net/MSF.475-479.97

${ }^{21}$ A. Zhang, X. Zhen, L. Qing, Effect of $\mathrm{Nb}$ on microstructure and properties of non-quenched and tempered steel with V-Ti combined addition used for crankshaft, Iron and Steel, 42 (2004) 1, 659-674, doi:10.13228/j.boyuan.issn0449-749x.2004.06.017

${ }^{22}$ Z. Yang, F. Wang, S. Wang, Intragranular ferrite formation mechanism and mechanical properties of non-quenched-and-tempered medium carbon steels, Steel Research International, 79 (2008) 5, 390-395, doi:10.2374/SRI07SP090-79-2008-390 